UDC $351 / 354$

DOI: https://doi.org/10.32782/2304-0920/2-81-17

\author{
Melnyk Mariia \\ Cao Zhuo \\ Sumy National Agrarian University
}

\title{
COMPARISON OF EDUCATIONAL MANAGEMENT OF CHINA AND USA
}

\begin{abstract}
With the development of world economy and political culture, there are different forms of modern education, the teaching method also emerge in endlessly. Education management is the important force to promote the development of education and change, it is through education management organization education team is coordinated, full play to the role of human education, financial, and other resources, and information is given. Using internal various favorable conditions, education management activities goal is to achieve high efficiency of education. Today, there are many problems existing in the education management, such as laws and regulations, education management system, education investment, education management is only skin deep, it has no substantial effect, so we will research China and the United States to find them in the higher education, science, education management research system and measures, and to find them in education management is worthy of our learning place.

Keywords: educational administration, educational system, development problems, comparison of managements, education teaching activities.
\end{abstract}

Formulation of the problem. Education is a unique social phenomenon that has a significant impact on all aspects of life and activity of the country, society, human civilization in general. In the modern scientific and technical and information revolution, education functions is a complex socio-economic organism, which plays a large role in the social progress. It is one of the most important branches of work and cognitive life.

The current stage of development of the educational system of China and the United States is characterized by its reform, the search for ways to bring content in line with students' personal requests, world standards.

Education reform is driven by the need to overcome the negative phenomena that occur in society. It is no coincidence that among the many transformations and upgrades of recent decades, special attention is given to those directly related to education and educational management.

Analysis of recent research and publications. The research literature in this paper mainly includes published monographs, journal papers and academic papers, network data and cases. Through Baidu, Google and other major Internet search engines, some literature materials related to the research topic were collected from the website of the ministry of education of PRC (http://www.moe.edu.cn/), the center for education statistics of the US department of education (http://nces.ed.gov/) and websites of universities in the USA and China, mainly collecting relevant data and cases.

Selection of issues that have not been solved previously. However, most of the scholars focus on particular systems of educational management in their work. The issues of studying the individual education systems of China and the USA, comparing them, examining their peculiarities in order to develop general and specific methods, tools, levers that would contribute to the effective development of the education system as a whole, are studied insufficiently.

The purpose of the article. The main purpose of this article is to find out the problems of current educational management by comparing the education system, education policy and educational management system in China and the United States, and to analyze and compare the problems in order to find out the solutions to the problems of educational management.

Outline of the main material. Along with the development of world economy and political culture, there are different forms of modern education, the teaching method also emerge in endlessly, and educational management, the important force to promote the development of education and change, it is through educational manager to organize and coordinate educational team, give full play to the role of the education of human, financial and material resources, and other information, using internal various favorable conditions, education efficiency is the realization of the goal of educational management activities. Nowadays, there are many problems in educational management, such as laws and regulations, systems, educational management is superficial and has no substantive effect [1, p. 2], we will take China and the United States as examples to find out their initiatives in higher education, subject curriculum, education management research, etc., and find out what they can learn in educational management.

Methodology and aim of the study. This study mainly adopts literature research, comparative research and data analysis.

1. Literature research method: the research literature in this paper mainly includes published monographs, journal papers and academic papers, network data and cases. Through Baidu, Google and other major Internet search engines, some literature materials related to the research topic were collected from the website of the ministry of education of PRC (http://www.moe.edu.cn/), the center for education statistics of the us department of education (http://nces.ed.gov/) and websites of universities in the us and China, mainly collecting relevant data and cases.

2. Comparative research method plays an important role in educational management research and is also the most basic method for analytical research.

3. Data analysis method: data analysis method has been widely used in all fields of social science research, including educational management research. In this paper, I will process and analyze the relevant data of the Chinese and American educational management to make a comparison.

Overview of higher education 


\section{(1) China}

1. The recruitment of students scale:

In 2018, there were 2940 institutions of higher education in China. Among them, there were 2663 institutions of higher education (including 265 independent colleges), 32 more than the previous year. There were 1245 regular undergraduate schools, 2 more than the previous year. There were 1418 vocational (junior college) colleges, an increase of 30 over the previous year. 277 adult colleges and universities, 5 less than last year; there are 815 graduate training institutions in China [1, p. 2].

Graduate enrollment in China reached 858000 (including 739300 full-time students), an increase of 51900 over the previous year, or $6.4 \%$, there has been recruited 95500 doctoral students and 762500 master's students.

China actively develops graduate education for professional degrees, strengthens the cultivation of application-oriented high-level talents, and optimizes the type and structure of talent cultivation. In 2018, 6784 doctoral students with professional degrees were enrolled, accounting for $7.1 \%$ of the total enrollment of doctoral students, an increase of $3.9 \%$ over the previous year. It recruited 439800 master's degree students, accounting for $57.7 \%$ of the total, an increase of $2.0 \%$ the previous year.

There were 7.9099 million undergraduate and junior college students in China, an increase of 295000 over the previous year, or $3.9 \%$. Adult college enrollment of 2.7331 million, an increase of 557,800 than the previous year, an increase of $25.6 \%$, which is a large increase.

2. Amount of students

In 2018, a total of 38.33 million people were studying in various types of higher education in China. The gross enrollment rate of higher education reached $48.1 \%, 2.4 \%$ higher than that of the previous year. The number of students in higher education per 100000 population, which was 2658 , 82 more than the previous year.

There were 2.7313 million postgraduates in China, an increase of 92700 over the previous year, or $3.5 \%$. Among them, there were 389500 doctoral students and 2341700 postgraduate students.

There were 28.313 million undergraduate and junior college students in China, an increase of 774500 or $2.8 \%$ over the previous year. There were 5.9099 million students in this college, an increase of 468400 or $8.6 \%$ over the previous year.

3 . Amount of graduates

In 2018, there were graduated 604400 postgraduates in China, an increase of 26300 or $4.6 \%$ over the previous year. Among them, 60700 graduated from doctoral programs and 543600 graduated from master's programs.

There were 7.5331 million college graduates in China, an increase of 174800 over the previous year, or $2.4 \%$.

4. The faculty of ordinary colleges and universities

The degree level of teachers in colleges and universities has been generally improved, and the structure of teachers has been further optimized. In 2018, there were 1.6728 million full-time teachers in ordinary institutions of higher learning, an increase of 39500 over the previous year, or $2.4 \%$. The ratio of students to teachers in ordinary colleges and universities is 1117.6 to 1 , the ratio of undergraduate colleges and universities among which was 17.4 to 1 , which was the same as that of the previous year. The ration of higher vocational (junior college) colleges was 17.9:1, compared with the previous year expanded.
The composition of teachers' degree levels continues to improve. In 2018, the proportion of teachers with graduate degrees in universities and colleges was $73.6 \%, 1.7 \%$ higher than the previous year. Among them, the number of undergraduate colleges was $83.7 \%, 1.7 \%$ higher than that of the previous year. Higher vocational (junior college) colleges were $50.0 \%$, an increase of $1.8 \%$ points over the previous year.

The proportion of teachers in senior professional and technical positions increased slightly. In 2018, the proportion of teachers holding senior technical posts in Chinese universities was $43.2 \%, 0.4 \%$ higher than the previous year. The figure for general undergraduate institutions was $48.7 \%$, up by $\mathbf{0 . 5} \%$ over the previous year. The figure for higher vocational colleges was $30.3 \%, 0.2 \%$ higher than that of the previous year.

5. Conditions for running an ordinary university:

The conditions for running schools in ordinary colleges and universities have been continuously improved, and the allocation level of teaching and research equipment, information equipment and online course resources, which are closely related to the improvement of education quality, has been further improved.

In 2018, the average size of the Chinese universities was 10605 , an increase of 175 over the previous year. Among them, there were 14896 undergraduates, an increase of 257 over the previous year. There were 6837 students in higher vocational colleges, an increase of 175 over the previous year.

In 2018, the average teaching assistance and administrative space for college students in China was 13.9 square meters, 0.1 square meters less than that of the previous year. Among them, the general undergraduate college was 13.2 square meters, 0.1 square meters less than the previous year; higher vocational (junior college) college was 15.3 square meters, 0.1 square meters less than the previous year.

The equipment configuration level of teaching and scientific research has been generally improved. In 2018 , the average value of teaching and research equipment per student in universities nationwide was 15,700 yuan, up $7.6 \%$ from the previous year. Among them, the average undergraduate college is $18300 \mathrm{CNY}$, an increase of $8.0 \%$ over the previous year; higher vocational (junior college) colleges reached $9875 \mathrm{CNY}$, an increase of $6.9 \%$ over the previous year.

In 2018 , there were 26.9 computers for every 100 students in universities nationwide, a slight increase of 0.2 over the previous year. Among them, 26.7 are regular undergraduate institutions, the same as last year; The number of higher vocational colleges was $27.5,0.7$ higher than that of the previous year.

(2) the United States

In the 2018-19 academic year, the number of post-secondary degrees awarded is expected to reach 985000 associate's degrees, 1968000 bachelor's degrees, 816000 master's degrees and 184000 doctoral degrees. The total number of doctorates includes most of the degrees, such as MD, DDS and law degrees, that were classified as the first major between 2010 and 2011 years ago. The number of degrees awarded increased at all levels between 2006-2007 and 2016-2017, data for the last years are available. Between 2006-2007 and 2016-2017, the number of associate's degrees increased by $38 \%$, the number of bachelor's degrees by $28 \%$, the number of master's degrees by $32 \%$, and the number of doctorates by $25 \%$. 
Between 2006-2007 and 2016-2017, the number of bachelor's degrees awarded to male students increased by $29 \%$, while the number awarded to female students increased by $28 \%$. In 2016-2017, female students received $57 \%$ of all bachelor's degrees, the same percentage as in 2006-2007. Between 2006-2007 and 2016-2017, the number of bachelor's degrees awarded to white students increased by $9 \%$, lower than black students (34\%), Hispanic students $(119 \%)$ and Asian/Pacific islander students (37\%). During that period, bachelor's degrees awarded to American Indian/Alaska native students declined by $16 \%$. In $2016-2017,64 \%$ of all white students received a bachelor's degree (2006-2007 it was 74\%), the black students obtained 11\% 10\% (2006-2007), Hispanic students received 14\% (compared with $8 \%$ in 2006-2007, the figure is 5\%), and Asia/Pacific islanders students income of $8 \%$ (7\% in 2006-2007). In two years, American Indian/Alaskan native students earned less than $1 \%$ of all bachelor's degrees. In 2016-2017, students of two or more races received $4 \%$ of all bachelor's degrees [2, p. 5].

In the fall of 2017, degree-granting institutions (defined as higher educational institutions that award associate's degrees or higher and are eligible for tier of federal financial aid) employed 1.5 million faculty members, including 800000 for fulltime and 700000 for part-time faculty. In addition, degree-granting institutions employ 400000 graduate assistants.

In terms of the number of colleges and universities, the total number of colleges and universities in the United States in the 2008-2009 academic year was 6 632, 4409 of which were accredited, including 2719 four-year colleges and 1690 two-year colleges. 2223 non-degree-granting institutions. In terms of student size, there were $20.428,000$ students enrolled in the US colleges and universities in the 2008-2009 academic year, including 12.906 million students enrolled in four-year colleges and $7.521 \mathrm{mil}-$ lion students enrolled in two-year colleges. There were 10.044 million undergraduate students and 2.862 million graduate students. In the financial aspect of higher education, the total revenue of public higher education degree-granting institutions in the United States was 267.4 billion USD in the 2008-2009 academic year. Non-operating income (mainly financial allocations from federal, state and local governments) was 9.24 billion USD, or $34.6 \%$; other revenue was 1.61 billion USD. In the business income, the tuition income is 5.18 billion USD, accounting for $19.4 \%$ of the total education income. The state government allocated 6.55 billion USD in operating revenue, accounting for $24.5 \%$ of total education revenue.

From the above, the scale of educational investment affects the scale of educational management. At the same time, the diversification of educational investment source, is also an effective way to increase the educational investment, therefore, increase educational investment is conducive to better realization of the educational fair, is conducive to more resources into educational industry, expand the scale of education, more advantageous to the operation of the stable and healthy education system, facilitating better implementation of the educational management system and policy.

The composition of higher educational disciplines and specialties.

On the one hand, compared with China, the United States has a more detailed division of disciplines and specialties. There are a total of 11 disci- plines, 73 specialties and 543 specialties in the catalogue of undergraduate majors in China [4, p. 21]. The United States has 38 subjects, 362 majors and 1,265 independent majors. In terms of quantity, the division of disciplines and specialties in the United States is more detailed than that in China, especially some applied disciplines. But the division of labor in the United States is based on a huge foundation [3, p. 17].

Learning stage, on the basis of "general education" at present, almost all American universities have detailed general educational plan, regulation lowerclassman must fix ManWenXue and art, history, natural science, social analysis and moral values, the foreign culture of "core curriculum", the composite talent cultivation of wide scope of knowledge. [7, p. 8]. On the other hand, compared with China, the United States attaches more importance to the development of cross-discipline, which exists as an independent academic group. Science and technology is the inexhaustible driving force of economic development, while the rapid development of modern science and technology is more and more dependent on the cross-integration of different disciplines, which is the inevitable trend of the development of science and technology. On the one hand, the research contents and problems themselves have the characteristics of cross-cutting, cross-penetrating of multi-disciplinary knowledge. On the other hand, the method used by researchers is highly centralized and intergenerational to some extent, that is, to study the problems of a certain discipline by means of one or more disciplines. Finally, the discipline structure in China presents a polarized state, mainly reflected in that the proportion of engineering disciplines accounts for more than one third of the total number of disciplines, while the discipline structure of the United States presents a relatively balanced state, with a small gap between engineering and the proportion of humanities, social sciences and other disciplines. Balanced development of disciplines is necessary for the overall discipline structure of a country [21, p. 27].

The educational system, therefore, depends on the establishment of good discipline system, both in America and other countries, China should have full, all-round, full coverage, and the national history, discipline system, development supplement each other, of course, even more with the development of modern science and technology as well as the continuation of human culture related disciplines.

Internal governance of public universities

The internal governance structure of public universities in China and that of public universities in the United States are very different in China and the United States due to the different resources and different responsibilities of each stakeholder in different subjects, which are mainly reflected in the following four aspects. According to the principle of decentralization, American public universities have established the power structure of decentralized management and the division of power between academic administrators and teachers. On the other hand, according to the principle of centralized management, the Chinese colleges and universities implement centralized management and administration-led power structure. Secondly, academic power and administrative power have different positions in the governance structure. Two kinds of power division in the American public universities cooperate and restrict each other. However, the imbalance between academic power and administrative power 
in the Chinese public universities is a prominent phenomenon. The internal self-supervision mechanism of the Chinese and American public universities has different functions. The American public universities have perfect rules and regulations on self-restraint, and adopt fair and open "sunshine policy" on university decision-making and management [22, p. 11]. The supervision mechanism of China's public universities cannot fully play its role, and the functions of various institutions are often formalized. School affairs are not open and transparent enough, and the rules and regulations of various power checks and balances are not sound enough [13, p. 7].

Educational administration of private higher education

Both China and the United States have incorporated private higher education into their respective higher educational management systems to varying degrees, and managed private higher education through the state educational administration department [23, p. 11] Private colleges and universities, as independent legal entities and subjects of interests, have also enjoyed the autonomy in running schools. First of all, from the perspective of the subject and administrative authority of national private higher education, the right to education in the United States is in the state, and the federal government has no right to directly manage private higher education [19, p. 44]. Although, the United States upgraded the department of education to a cabinet-level department of education in 1979, the administration of the department of education was limited to exercising indirect control over the private higher education through various legislative and financial appropriations passed by congress and maintaining indirect influence over private higher education through accreditation of various accrediting agencies. The state administration of private higher education is governed by a legislature with a decision-making function [16, p. 9].

There are executive functions of the state education committee composition, the state has no direct supervision and inspection system but in school. In the examination and approval, financial audit, tax inspection, construction facilities inspection and other aspects, private colleges and universities generally implement state management. In China, the central unified macro-management and the local decentralization of specific management [11, p. 5]. The administrative management of the privately-run higher education is embodied in running schools at all levels, management at all levels and responsibility at different levels. The provincial administrative department of education is the main administrative department. On the other hand, private colleges and universities set standards. The power of decision and approval is concentrated in the school management office of the central ministry of education of social forces and most provincial schools in China [25, p. 9].

Up to now, the government has not established a corresponding special management institution for private higher education, and the government's management of private colleges and universities is insufficient [20, p. 11]. Secondly, from the perspective of management methods, apart from the direct administrative approval and supervision of private universities, the American government also attaches great importance to the indirect management of private universities through educational intermediary organizations. The management method is flexible and the characteristics of private higher education and market economy are compared. The Chinese government's approach to governance is relatively unitary.
China mainly emphasizes the role of the government in management, and few educational intermediaries participate in the management process [5, p. 9].

Therefore, to improve the management and supervision system of private education and encourage the development of private education, of course, the government also needs to guide private education to a good direction, and support private education from the aspects of funds, policies, public opinion, etc. In addition, it is necessary to improve the supervision and evaluation system of the privately-run education, and make use of laws, regulations and public opinion to supervise the privately-run education, and the privately-run education itself should also improve its own evaluation system.

Educational administration system.

Comparison of educational administrative power between the Chinese and American educational administrative systems.

Through the comparison of the educational administrative power between China and the United States, we can find out that the United States has been experiencing the reform from the decentralization system to the educational equal rights system. Of course, decentralization has both disadvantages and advantages [6, p. 9].

The advantages are:

Firstly, it can fully mobilize the enthusiasm and sense of responsibility of local education; secondly, to adapt to the political and economic needs of the region, so as to achieve the development of education according to local conditions; thirdly, it can conduct experiments in combination with the local conditions, and compete and promote each other through the experiments and creation of different regions [15, p. 64].

Its disadvantages are:

Firstly, it is easy to cause their own things, the quality of education is uneven;

Second, it is easy to lead to the imbalance of educational development, and the principle of equal educational opportunities is difficult to achieve.

China, on the other hand, is following the transformation from centralization to equalization.

The advantages of centralization are:

Firstly, to fully mobilize the enthusiasm of the central education;

Secondly, the principle of equal educational opportunities can be brought to bear on the whole country.

Thirdly, it is conducive to the general improvement of the quality of education.

Disadvantages of centralization:

Firstly, the local lack of autonomy to run education.

Secondly, it is easy to be divorced from local reality and hinder the development of education.

Thirdly, it does not encourage free experiments and restricts the enthusiasm of local governments in exploring educational and teaching reform. With the development and reform of the educational administrative systems in China and the United States, both countries are moving in the same direction, with equal power at the same level. The advantage of the equal-power system is that it can not only guarantee the unified management of the central government, formulate the common educational policy and policy, but also consider the local characteristics, develop the local educational undertakings according to the local conditions, and promote the enthusiasm and responsibility of the local education departments. [18, p. 20]. However, there are more disadvantages: this type of countries in central and local, the gov- 
ernment and the school, the management way on the intervention and guidance, strict and loose relationship is more difficult to deal with good, both under the condition of different emphasis, arguably more difficult to grasp of the scale of the relations between the two aspects, will bring some adverse effect on the development of education [10,p. 7].

Comparison of administrative independence in educational administrative system between China and the USA.

Through the comparative study of educational administrative independence between China and the United States, it is not difficult to see that the United States implements the forms of subordination, independence and semi-independence respectively in three levels of federal, state and school district [24, p. 3]. Under the overall management of the federal government, states and school districts can develop education in accordance with local conditions, and can better mobilize the enthusiasm of local education development [14, p. 7]. However, from the perspective of both sides of the issue, it also has some disadvantages: education involves a lot and has a deep impact on other departments. If separated, it will easily lead to the waste of resources and poor communication [12, p. 5].

However, in China, from the ministry of education to all the provinces, cities and counties, the education departments have implemented the subordinate system. The advantages of the subordinate system are:

Firstly, it is conducive to the initiative of the government in running undertakings and the establishment of an educational administrative system that is in line with China's political progress and economic development. Secondly, gives the government more power to command the work of lower departments and schools with more authority $[17, \mathrm{p} .8]$.

Comparison of the leading decision-making systems of the educational administrative systems in China and the United States.

It is possible to understand from the comparative study of the educational administrative leadership decision-making system in China and the United States that the United States generally adopts the collegial system, and only the federal educational personnel management is the responsibility of the President, namely the directorate system.

The advantages of collegiality are:

Firstly, to accept the different views of the committee members, collect more information;

Secondly, through the discussion of all people, it gets consensus, unified implementation.

Thirdly, it does not use favoritism to bend the law while supervising and promoting each other.

However, collegiality has its drawbacks:

Firstly, it is not conducive to overall consideration, and easy to shirk responsibility;

Secondly, without supreme leadership, it is not easy to coordinate disputes.

The principal responsibility system is implemented in China, which has both the advantages of collegial system of collective wisdom, mutual supervision and overall consideration, and the advantages of clear division of labor and unified command of the leader system. The effective management and supervision of the government is conducive to the improvement of the education system and the development of education, but the management and supervision are not very strong, so it is necessary to give the education system some space and make the education power a little independent, which is more conducive to the development of academic research.
Conclusions and suggestions. Therefore, if we want to improve the quality of educational management, we should do the following:

1. Increase the investment of education funds, actively publicize the enrollment of colleges and universities, expand the enrollment of colleges and universities, and expand the coverage of higher education.

2 . In terms of the subject composition and subject setting of higher education, it is necessary to pay attention to the development of cross-discipline in order to better meet the needs of economic development. The establishment of discipline investigation committee, the better establishment of the discipline curriculum system in line with the characteristics of the country, the establishment of a rigorous evaluation mechanism. Of course, we should learn the advanced curriculum system of other countries.

3 . In the internal governance of public university, on the one hand, perfecting university organization all stakeholders game rules of the articles of association of the university, establish and perfect rules and regulations and behavior rules of power balance, strengthen the supervision, inspection and the regulation of further development of the university organization since it constraints mechanism, forming perfect, clear and effective supervision and evaluation system, is the prerequisite for the implementation of the above reform will have effect. In the construction and management of a university, if only the autonomy of the university is emphasized, and the sound rules and regulations, supervision mechanism and social responsibility of the university are not stressed, the problem of abuse of power in the process of running a school or the difficulty in ensuring the credibility of running a school will arise. Only let the powers, interests, functions, decisions, between superior and subordinate, between institutions and members of the mutual control, mutual supervision, can truly build the power and responsibility consistent, reasonable division of labor, scientific decision-making, smooth execution, strong supervision of the university organizational governance structure. On the other hand, we should add importance to the power of teachers and scholars, who are the most important stakeholders of university organizations, strengthen the role of faculty and staff in the governance structure of university, and gradually promote the establishment of the teaching and governance system.

4. In private higher education, strengthen the legal construction, ensure the legal status of private higher education, promote the democratic and efficient administrative management system, and improve the supervision and evaluation mechanism. The government should give more support to the private universities independently and in policy.

5. To expand the independent power of colleges and universities, and the government should make use of social resources and social forces. Establish a professional educational administrative team to establish educational administrative associations to promote exchanges and cooperation between regions and countries.

In addition, it is necessary to improve the domestic and foreign cooperation mechanism, strengthen the exchange with foreign advanced educational management experience, learning the merits. It is necessary to improve the research method system of educational management, establish authoritative academic journals of educational management, enrich research methods of education management, and strengthen the application of statistical methods of education management research. 


\section{References:}

1. Anqi - problems and solutions in the management of higher education in the new era - Drama House - 2018.10.24.

2. Chen Yujie - comparative study on the discipline structure of higher education in China and the United States - Tianjin university - 2012.05.01.

3. Chen ling - The realistic needs and paths of teacher education specialty construction - Contemporary teacher education- 2019.03.15.

4. Dong Fuping - a comparative study of higher education evaluation systems in China and the United States - Wuhan university of technology - 2005.10.01.

5. Dong Lin - a comparative study on educational administrative systems between China and the United States - Henan normal university - 2013.05.01.

6. Fan yongsheng - Liang huiqing - Experience and enlightenment of vocational education management system in developed countries - Journal of liuzhou vocational and technical college-2019.04.30.

7. Huang Zhaoxin - Zhao guojing - a comparative study on entrepreneurship education curriculum system in Chinese and American universities - a study on higher education in China -2015.01.20.

8. Li guoliang - The history, types and enlightenment of the governance relationship between American public universities and state governments- Research on higher education in chongqing - 2020.01.16.

9. Li Ruifang -a comparative study of private (private) higher education policies in China and the United States-nanchang university - 2010.01.05.

10. Liu Yuanyuan - policy analysis and comparative study on the construction of world-class universities in China and the United States - Lu Dong university - 2019.06.01.

11. Lu Yingjie - The idea of American for-profit university and its enlightenment- The Chinese market - 2019.06.03.

12. Ma Yifei - research on international education policy in China and the United States - theory and case analysis from a comparative perspective - east China normal university - 2014.04.01.

13. Niu Huanxia - comparison of internal governance structure of sino-american public university -research on science and technology higher education - 2010.04.15.

14. Qiu Bo-a comparative study on the management systems of teachers in Chinese and American primary and secondary schools - Guangxi normal university - 2016.05.01.

15. Ran yahui- On the triple logic of Chinese university governance in the new era - Guizhou social science - 2020.3.20.

16. Wang Jing - a study on the differences in the application of educational management research methods between China and the United States - central China normal university - 2012.05.01.

17. Wang zhanrui- Research on the construction of the governance evaluation index system of universities with Chinese characteristics- Journal of Beijing university of technology (social science edition) - 2020.03.20.

18. Xiang aiguo- The connotation, dimension and enlightenment of American university governance structure- Contemporary educational practice and teaching research - 2020.03.10.

19. Xie bo- Financing channels and inspiration of American private universities- Hunan normal university-2013.03.01.

20. Yang Zhixiang - comparative study on the management of private higher education in China and the United States - university of electronic science and technology - 2007.10.01.

21. Ye Jianhua - a comparative study on the professional degree curriculum system of Chinese and American masters in education - a case study in the direction of education management - Zhejiang normal university - 2012.05.14.

22. Yin Lili-history of sino-foreign cooperative education in higher education - xiamen university - 2014.04.01.

23. Yang sha- Research on financing mode of private universities in China - Research on private higher education - 2020.03.30.

24. Yang runyong- Research on the policy adjustment of educational management system in China under the new backgroundEducation research - 2011.03.15.

25. Zhang wenfeng - The analysis of the factors that promote the development of American private higher education and its enlightenment - Hunan university - 2008.11.17.

\section{Список використаних джерел:}

1. Anqi - problems and solutions in the management of higher education in the new era - Drama House - 2018.10.24.

2. Chen Yujie - comparative study on the discipline structure of higher education in China and the United States - Tianjin university - 2012.05.01.

3. Chen ling - The realistic needs and paths of teacher education specialty construction - Contemporary teacher education2019.03.15.

4. Dong Fuping - a comparative study of higher education evaluation systems in China and the United States - Wuhan university of technology - 2005.10.01.

5. Dong Lin - a comparative study on educational administrative systems between China and the United States - Henan normal university - 2013.05.01.

6. Fan yongsheng - Liang huiqing- Experience and enlightenment of vocational education management system in developed countries- Journal of liuzhou vocational and technical college -2019.04 .30 .

7. Huang Zhaoxin - Zhao guojing - a comparative study on entrepreneurship education curriculum system in Chinese and American universities - a study on higher education in China - 2015.01.20.

8. Li guoliang - The history, types and enlightenment of the governance relationship between American public universities and state governments - Research on higher education in chongqing - 2020.01.16.

9. Li Ruifang -a comparative study of private (private) higher education policies in China and the United States-nanchang university - 2010.01.05.

10. Liu Yuanyuan - policy analysis and comparative study on the construction of world-class universities in China and the United States - Lu Dong university - 2019.06.01.

11. Lu Yingjie - The idea of American for-profit university and its enlightenment - The Chinese market - 2019.06.03.

12. Ma Yifei - research on international education policy in China and the United States - theory and case analysis from a comparative perspective - east China normal university - 2014.04.01.

13. Niu Huanxia - comparison of internal governance structure of sino-american public university -research on science and technology higher education - 2010.04.15.

14. Qiu Bo-a comparative study on the management systems of teachers in Chinese and American primary and secondary schools - Guangxi normal university - 2016.05.01.

15. Ran yahui- On the triple logic of Chinese university governance in the new era - Guizhou social science - 2020.3.20.

16. Wang Jing - a study on the differences in the application of educational management research methods between China and the United States - central China normal university - 2012.05.01.

17. Wang zhanrui- Research on the construction of the governance evaluation index system of universities with Chinese characteristics - Journal of Beijing university of technology (social science edition) - 2020.03.20.

18. Xiang aiguo - The connotation, dimension and enlightenment of American university governance structure - Contemporary educational practice and teaching research -2020.03 .10 . 
19. Xie bo- Financing channels and inspiration of American private universities - Hunan normal university - 2013.03.01.

20. Yang Zhixiang - comparative study on the management of private higher education in China and the United States - university of electronic science and technology - 2007.10.01.

21. Ye Jianhua -a comparative study on the professional degree curriculum system of Chinese and American masters in education - a case study in the direction of education management - Zhejiang normal university - 2012.05.14.

22. Yin Lili-history of sino-foreign cooperative education in higher education - xiamen university - 2014.04.01.

23. Yang sha- Research on financing mode of private universities in China- Research on private higher education -2020.03 .30 .

24. Yang runyong- Research on the policy adjustment of educational management system in China under the new backgroundEducation research - 2011.03.15.

25. Zhang wenfeng - The analysis of the factors that promote the development of American private higher education and its enlightenment - Hunan university - 2008.11.17.

\section{Мельник М. И.}

Цзао Чжуо

Сумский национальный аграрный университет

\section{СРАВНЕНИЕ ОБРАЗОВАТЕАЬНОГО МЕНЕАЖМЕНТА КИТАЯ И США}

\section{Резюме}

С развитием мировой экономики и политической культуры появляются различные формы современного образования, также бесконечно появляются различные методы обучения. Управление образованием является важной силой, способствующей развитию образования и переменам, скоординированной работе команде образования в организацииях управления образованием, в полной мере играеть роль в человеческом образования, финансовых и других ресурсов и информации. Используя различные внутренние благоприятные условия, цель деятельности управления образованием заключается в достижении высокой эффективности образования. Сегодня существует много проблем, существующих в управлении образованием, таких как законы и нормативные акты, система управления образованием, инвестиции в образование, управление образованием - это очень углубленная тематика, поэтому мы будем исследовать пример системы управления образования в Китае и Соединенных Штатах, рассмотрим их систему в области высшего образования, науки, управления образованием.

Ключевые слова: управление образованием, образовательная система, проблемы развития, сравнение управлений, педагогическая деятельность.

\section{Мельник М. I.}

Цзао Чжуо

Сумський національний аграрний університет

\section{ПОРІВНЯННЯ ОСВІТНЬОГО МЕНЕАЖМЕНТУ КИТАЮ ТА США}

\section{Резюме}

Поряд з розвитком світової економіки та політичної культури існують різні форми сучасної освіти, метод викладання також виникає в нескінченному періоді, а управління освітою - важлива сила сприяння розвитку освіти та змін, саме через управління освіти потрібно організувати та координувати навчальний колектив, повною мірою реалізувати роль освіти через людські, фінансові та матеріальні ресурси та джерела інформації, використовуючи внутрішні різні сприятливі умови, оскільки ефективність освіти залежить від реалізації мети діяльності управління освіти. Динамічне суспільство знань потребує активного розвитку неперервної освіти. Організація вищої освіти має бути гнучкою, швидко реагувати на зміни у навколишньому середовищі, в тому числі на мінливі вимоги ринку праці і глобалізаційні виклики у постіндустріальному суспільстві знань. У світлі цих вимог і тенденцій потребує модернізації система управління вищою освітою. Пошук нових управлінських рішень щодо створення ефективної інфраструктури безперервної освіти є нагальним завданням розвитку освітніх систем усіх країн світу за умови збереження національних традицій і пріоритетів. Сьогодні в управлінні освітою виникає багато проблем, таких як недосконалість законів та нормативних актів, системи управління освітою є поверхневим $\mathrm{i}$ не має суттєвого впливу, тому ми проаналізуємо систему управління освітім процесом Китаю та США як приклади для 3'ясування їхніх напрямів розвитку управління в освіті, розглянемо навчальні програми, дослідимо систему управління освітою та з'ясуємо, чому саме ми можемо навчитися в управлінні освітою. Основна мета цього дослідження - з'ясувати проблеми сучасного управління освітою шляхом порівняння системи освіти, освітньої політики та системи управління освітою в Китаї та США, а також проаналізувати та порівняти проблеми, для пошуку шляхів їх вирішення. Управління освітою є важливою ланкою в навчально-виховній діяльності, полягає в забезпеченні безперебійної реалізації освітньої політики, ключових кроків для забезпечення якості викладання, є потужною мотивацією, однак, з розвитком економічних і політичних систем, існує багато проблем у сучасному світі, а саме в управлінні, а отже вирішення цих проблем матиме великий вплив на розвиток освіти в цілому. У цьому документі наведено системи освітніх сфер Китаю та США як приклади для порівняння їх заходів щодо управління освітою. Також розкрито питання діяльності органів державного управління освітою Китаю та США, визначено фактори, що забезпечують успішність управлінської діяльності.

Ключові слова: адміністрація освіти, освітня система, проблеми розвитку, порівняння управлінь, навчально-виховна діяльність. 